\title{
TV Broadcasting in Turkey. The Turkish Television Audience in the Frame of Uses and Gratification Approach
}

\author{
By Mihalis Kuyucu*
}

The aim of this paper is to give detailed information about the television industry of Turkey from the perspective of the audience. The first part of the paper is a conceptual analysis of "Uses and Gratification Approach". The second part is an evaluation from the audience perspective to the Turkish television industry in the frame of Uses and Gratification approach and includes a review of the previous researches done in the world and Turkey for the television audience in the sight of this approach. The research will apply a survey of 833 people who had graduated from university of Istanbul to specify the reasons of "why the university graduated Turkish audience watch television", "how do the university graduated Turkish audience watch television" in the frame of Uses and Gratification approach. The paper will make a determination the about the television consuming habits of Turkish audience in the sight of technological use, media time and distribution.

Keywords: television, television broadcasting, Turkey, TV ratings, uses and gratification

\section{Introduction}

Mass Communication Theories try to explain the power and the place of communication tools in the economic, political and social order. The changes in world conditions and technologies from the $19^{\text {th }}$ century to the $20^{\text {th }}$ had tremendous impacts on both societies and mass media.

Theoretical works on communication and media have developed parallel to each other in countries like the USA, England, France and Germany and in Northern Europe. The behaviourist and empiricist traditions in the USA, Frankfurt School in Germany, the structuralist and poststructuralist approaches in France and the cultural studies in the United Kingdom that emerged after 1970s were formed through the intersection of theories from different disciplines. The audience based research emerged in the USA in the 1940s and was discussed intensively in Europe during the 1980s and 1990s.

With a history that goes back to the beginning of the $20^{\text {th }}$ century, mass communication research might be defined from many different perspectives. Mass communication research might be assessed and classified in terms of the medium being researched, audience, the subjects discussed, issues and process.

The topic of "effect" has an important place in mass communication and media studies. In the first period of the media research history, it was accepted

\footnotetext{
${ }^{*}$ Assistant Professor, Faculty of Communications, İstanbul Aydın University, Turkey.
} 
that media has the power to shape and change the opinions and beliefs and to frame behaviours.

Communication scientists evaluate mass communication research from different perspectives. Theories presented in the field of communication were classified in terms of historical periods. In the first period of mass communication research, which lasted until the 1930s, the concept of "effect" was dominant. It was believed that mass media had the power to shape the ideas and beliefs, to change and shape the flow of life and behaviours, and, moreover, to make the political systems accepted even though there was resistance. These opinions were based on the observations on the increased popularity of the press, cinema, radio and the increased number of audiences (Koçak, 2001, p. 6). During that period, it was believed that mass media had the power to manipulate people. Therefore, mass media was used as a propaganda tool by political authorities.

The years between 1940 and 1960 are considered as the second period of mass communication research history. The studies of the previous period that emphasized the concept of "effect" were rejected and it was believed that mass media had little effect on people.

The studies of the second period of communication research focused on attitude formation and attitude change and therefore measurement techniques became important. Social issues like sexuality and violence were chosen as research topics. The data acquired in this period was not enough to make conclusive statements on the effect of media on people (Yumlu, 1994, p. 49). Uses and Gratifications' theory is one of the leading theories tries to answer this question. The main purpose of "Uses and Gratifications Approach" is to provide such information and try to understand audience's media choice. The core question is "why do people use media?" and "what do they use media for?". According to Uses and Gratification Approach, audience/consumers choose media by considering its potential to fulfil their needs. There are objective relations between content transmitted by mass media and the gratification arising from individual's instinctive interest (Türkoğlu, 2007, p. 118). "Uses and Gratification Approach" revealed that people prefer entertainment shows rather than informational TV shows. Entertaining oneself became much easier than acquiring information as a result of the developments in communication technologies, especially beginning with the developments in the 1970 s.

Television has been a popular mass communication tool since the first television broadcasts started in the 1930s. Today, television is more than a technological device. It is a field where economic, social and cultural production, consumption and reproduction take place as well as being a means of socialisation. Television, as a medium that appeals to the eye and the ear, captures the interest of the person and does not let him engaged in anything else. A person cannot read a book or produce something while watching television. Anyone who sits in front of television immediately becomes a slave to it. Hüseyinoğlu compared television to the Trojan Horse. Television is the Trojan Horse that functions as the sneaky tool and carrier of the Western Culture. Materialist and capitalist countries, which 
want to destroy all human values and make their cultures dominant all over the world, and their recruits in the Islamic Societies, actively use television (Hüseyinoğlu, 2009, p. 10). Cultural elements are transferred from one generation to the next and, today, it is through television that the cultural elements that would continue, change or be excluded are transmitted to the audience. Another significant function of television in the transmission of culture is that it enables the transmission of the extra-societal cultures. Extra-societal values, cultural templates and behavioural patterns are transmitted via television as well (Aziz, 1982, p. 30). We can say that, television is an important medium that entertains people, takes them away from the daily life and depicts a fantasy world (Tezcan, 1982, p. 106107).

Television, particularly in the 1950s, dethroned the radio and became one of the most powerful media sources in the world. In Turkey, it started to become widespread in the 1980s, but the actual proliferation occurred after the 1990s. Until then, television broadcasting was made under state control. But 1990 , with the birth of the privately funded television channels, media industry has begun to change in Turkey. The first private television broadcast was made on May 7, 1990 by the channel Star 1, which was established by the Uzan Holding. Beginning with this date, there has been a significant increase in the number of private television channels. Research conducted on January 1993, showed that there were 76 television transmitters throughout Turkey at that time (Çapl1, 2008, p. 140). The number of television channels, which was 1485 in the year 2000, increased up to 1585 in 2010 (Dede, 2011, p. 16). In 2012, the number of television channels broadcasting in Turkey increased to 1784 (TÜIK, 2014). Today, television receives the largest share from the advertising budgets. In 2012 , television got the $56 \%$ of expenditures ${ }^{1}$ which increased to 57, $24 \%$ in April $2014^{2}$. Television receives $43,82 \%$ of the global ad expenditures $^{3}$. The difference between these two data indicates that, in Turkey, television has more power in comparison with the world average.

In parallel with the growth in the television industry since 1990s, the number of television audience research increased beginning from the 1980s, but particularly during the 2000s. This increase was partly due to the academic studies and market research conducted, which served the industry in its commercialising process. But, the change in the definition of the audience and their positions as a result of the technological developments, were also influential. Due to these changing conditions, the function of television was started to be discussed and questioned more than before. In these discussions, the focus was on the audience interaction with television and the way audience uses television. In this study, the use of the television medium is discussed by using "Uses and Gratifications Approach" and the gratifications obtained by Turkish television audience are explored. In addition, the ways that television audience uses this media and the place of television in the lives of Turkish audience are examined.

\footnotetext{
${ }^{1}$ See: http://www.sabah.com.tr/Ekonomi/2013/03/14/reklam-pazari-5-milyara-kosuyor 12.06. 2014.

${ }^{2}$ See: http://rd.org.tr/doc/RD_TABLO_2014_NISAN.pdf, 03.07.2014.

${ }^{3}$ See: http://www.mediacatonline.com/reklam-harcamalari-2014te-yuzde-45-buyuyecek/, 04.07.2014.
} 


\section{Uses and Gratifications Theory}

Uses and Gratifications Theory is an approach that was developed in order to explain the process of mass communication. It states that individuals fulfil their sociological and psychological needs by using media. Rubin accepted Uses and Gratifications Theory as a sub-tradition of media effect research, whereas McQuail and Windahl emphasized the fact that this theory was focused on the question "what do people do with media", not "what does media do to people" (Çakır and Bozkurt, 2014, p. 63).

The roots of uses and gratifications theory, which conceives the audience members as active communicators, could be traced back to the works conducted by the Bureau of Applied Social Research in the 1940s (Karakoç and Gülsünler, 2012, p. 45). Uses and Gratifications Theory was stemmed from the functionalist research in social psychology on the formation of perception, attitude and norms. The understanding of selective perception comes from the literature of perception and says that people's needs and interests influence the things that they can and cannot receive in a given environment. The suggestion that individual differences will result in different subjective understandings in the same objective environment is adapted to the perception of the media message. The same media message could be perceived differently because of their different needs and interests (Koçak, 2001, p. 56).

Elihu Katz was among the first academicians who mentioned the Uses and Gratifications Approach. This approach came up in reaction to Berelson's criticism, which claimed, "the field of communication research seemed to be dead" It is based on the assumption that audience members actively seek out mass media content that best fulfils their needs. This approach examines the gratification obtained from media in a systematic way. By asking the question "what do people use media for?" it emphasizes the ethnographic research on the user gratification, audience members and message reception (Akçay, 2011, p. 139-140). The research on "how do housewives use radio soap operas and what gratifications they give them" which was conducted in the 1940s, added human element into the communication theory and led uses and gratifications theory to come to the forefront (Özarslan and Nisan, 2011, p. 27).

Uses and gratifications approach focuses on the choice, perception and attitude of the media audience. The audience member makes a conscious and motivated choice among the presented media contents. According to this audience-centred approach, real source of the meaning of media experience could be obtained from personal motivations. This process indicates a structure, which is interactive, related to media content, based on individual needs and pays attention to social context.

Katz, as one of the advocates of this approach, focused on the question "what do people do with media?" (Alikılıç, Gülay \& Binbir, 2013, p. 42). He stated that humans have psychological and social needs that should be fulfilled. Some of these needs might be about releasing tension or escaping from the stress of daily life. Escape, entertainment and passing time are regarded as 
psychological needs in our era (Demir \& Demir, 2013, p. 5). The theory has five basic assumptions (Çakır \& Bozkurt, 2014, p. 64):

- the audience is active;

- audience members initiate the selection and use of communication vehicles;

- media is not the only source of need satisfaction;

- people are aware of their motives and needs;

- value judgments about the cultural significance of mass communication should be suspended while audience orientations are explored.

It is also stated that Uses and Gratifications Theory has three main agendas:

- to explore how people use mass media to satisfy their needs;

- to discover the underlying motives for using mass media;

- to identify the positive and negative outcomes of individual use of mass media.

Karakoç and Gülsünler presented three basic findings about the theory: (a) the audience is active - it is not a passive receiver of whatever the media broadcast - it selects the program content; (b) audience members freely select the media and the programs that they can best use to gratify their needs; (c) different people may use the same program to gratify different needs -still it is possible to identify some basic motivations for the approach (2012, p. 46).

This approach sees the use of media as the gratification and tension process of needs and accepts mass media audience members as active and rationalist individuals who resist against the effects and make choices based on their needs and wants. According to uses and gratifications approach, people have individual and social needs and these needs could be fulfilled by taking different actions. When there are not any means to satisfy needs or, even if they are available, when they are not sufficient, people try to gratify these needs with functional options. When social and individual entities get in touch with the needs, differentiated, individual problems arise which lead to different motivations in seeking gratification. As a result of this whole differentiation process, media is used in different ways and for different purposes. The model Rosenberg developed for the uses and gratifications research presented in Figure 1. 
Figure 1. Uses and Gratifications Paradigm

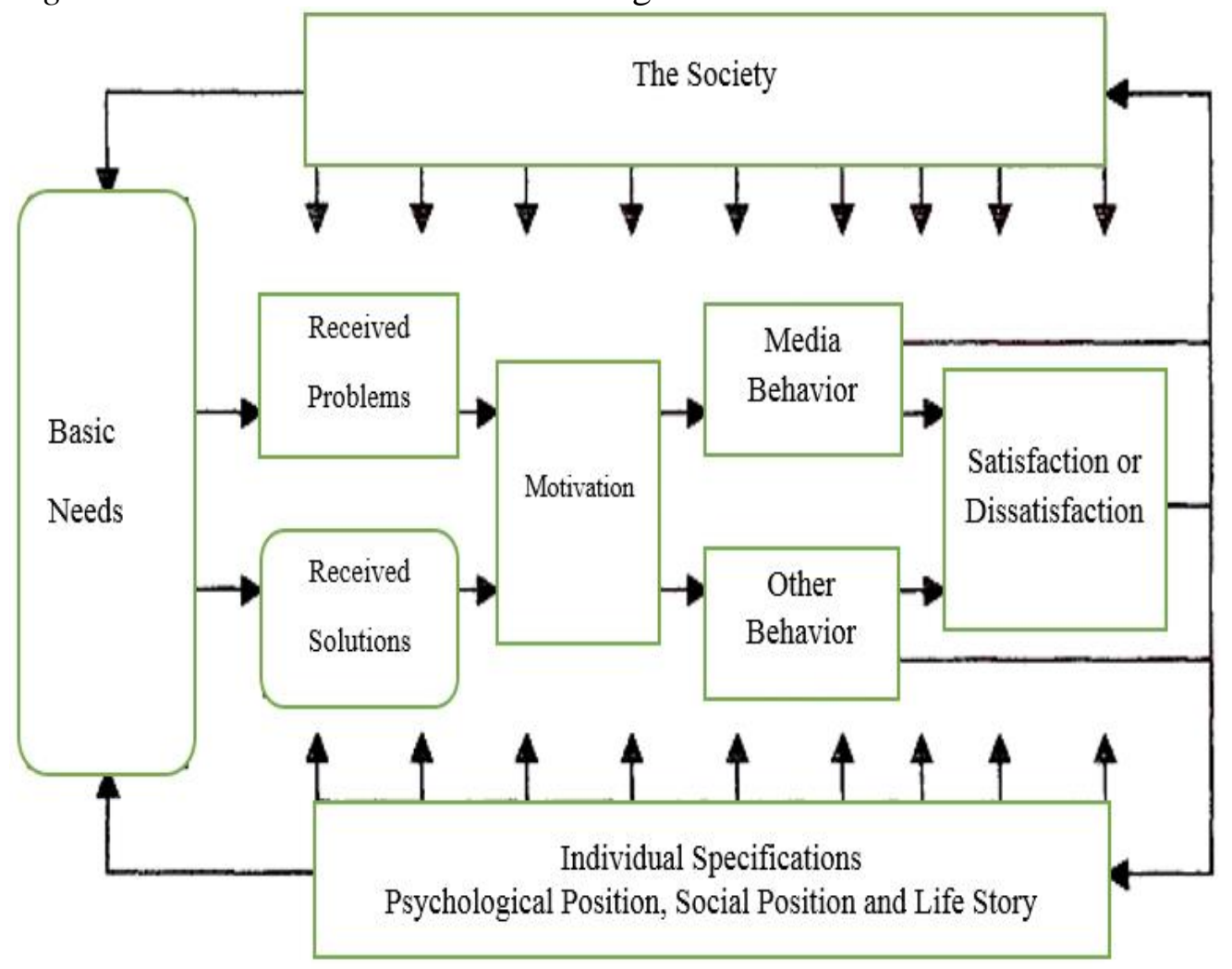

Source: Koçak, 2001, p. 59.

Rosenberg's model starts with the "basic needs" of the individual. It is stated that, in order for the needs to transform to actions, they should be perceived as problems and also, the possible solutions for those needs should be perceived. Individual specifications and social structure and their role in the satisfactions of needs are other important factors that should be considered.

According to studies which are based on the Uses and Gratifications Theory, reasons of watching television are listed as (a) diversion, escape: distancing from the routine and limitations of daily life, escaping from the problems and emotional release; (b) personal relationships: companionship; (c) personal identity: self-reference, reality exploration; (d) surveillance: awareness of the agenda (Özçetin, 2010, p. 16)

\section{Uses and Gratifications Research on Television}

Uses and Gratifications Theory was used in studies that examine the people's motives for watching television for the first time in the 1960s. Since then, the perspective that sees audience members as passive has started to change.

In the literature of Uses and Gratifications Theory, the most interesting studies were conducted on television audience. McQuail et al. classified 
the needs fulfilled by television as follows (a) diversion: escape from the problems of daily life, entertainment; (b) personal relationships: establishing relationships through television, feeling less lonely; (c) personal identity: link between the audience and program content, information acquisition about possible problems, value reinforcement; (d) surveillance: information about the world events, knowledge acquisition (as cited in Aydin, 2007, p. 120-121).

Gerson's research in 1966 asserted that race was an important factor in media use. The research by Katz and Faulkes "On the Use of the Mass Media as Escape" (1962), Mendelsohn's research on the use of radio (1964), the study of Greenberg and Dominick examining the use of television by children between 11-18 as a source of information (1969) were among the important studies conducted in the 1960s which were based on Uses and Gratifications theory (as cited in Ruggiero, 2000, p. 5-6).

In the 1970s, empirical research, based on the Uses and Gratifications Theory, continued. Different field researches about media use were conducted during this period. McLeod and Becker's "Testing the Validity of Gratification Measures through Political Effects Analysis" and Johnstone's "Social Integration and Mass Media Use among Adolescents: A Case Study" were significant studies of the period (as cited in Ayhan and Çavuş, 2014, p. 39).

According to the research on the British television viewers conducted by Blumler, McQuail and Brown in 1972, people were using television for diversion, personal relationships, personal identity and surveillance. Television was functional in escaping from the routine, getting rid of the problems, releasing tension, establishing parasocial relationships rather than social relations, participating in the discussions and obtaining information (as cited in Küçükkurt, Hazar, Çetin \& Topbaş, 2009, p. 38).

Greenberg's study on motivations and gratifications of children and adolescents (1974) is now considered as a classic research model. In this study, he identified seven basic motives for watching television (relaxation, companionship, learning, habit, filling time, arousal and escape) (as cited in Çakır \& Bozkurt, 2014, p. 65).

Rubin (1985) and Rosenbren as well as Wenner and Palmgreen (1985) stated that main factors for which people watch television are entertainment or diversion, social utility and personal relationships, information search and personal identity (as cited in Koçak, 2001, p. 79). Uses and Gratifications researchers indicated that variables such as age, gender, income, social class, ethnic origin and profession are influential on media use and personal choices.

Fiske (2003, p. 195-196) notes that most of the audience use quiz programs for four main gratifications. These are (a) self-rating; (b) social interaction; (c) excitement (d) education. As for the crime series, gratifications that the audience obtain are (a) excitement/escapism; (b) information; (c) reassurance. Although different researchers could categorize gratifications differently, it could be said that there are four main categories: 
1. diversion (escape from the constraints of routine, escape from the burdens of problems, emotional release);

2. personal relationships (companionship, social utility);

3. personal identity (personal reference, reality exploration, value reinforcement);

4. surveillance (Fiske, 2003, p. 198).

Livaditi, Vassipoloulou, Lougos \& Chorianopoulos (2003, p. 100), in the empirical study conducted to understand and categorize viewers' needs in the context of digital TV applications, identified five motivations. According to him, main motives for watching digital television are entertainment/ companionship and escape. Researchers listed other needs of the digital television subscribers as utilisation, information and awareness. They stated that the primary reason for digital television subscribers to use this media is for fulfilling their daily needs and the reason following it is to gratify entertainment needs.

Lull categorized use of television as structural and relational. In the structural use, television is an environmental source and accompanies the individual. In addition to the entertainment and informational purposes, audience also use television simply to escape from routine (Lewis, 2008, p. 257) (Table 1).

The common characteristic of the studies, which are based on uses and gratifications approach is that they start off with the assumption that people have social and psychological needs and they seek media contents to gratify these needs. People can fulfil their needs by consuming specific media content. For example, watching a television program might gratify a viewer's need for entertainment while another viewer who needs information can gratify this need by reading a book or an essay (Yaylagül, 2006, p. 62-63).

Television studies, based on the Uses and Gratification Theory, focused on the fact that television fulfils the entertainment needs of people. At the beginning, television broadcasts were structured according to the audience's free time, but over time, they began to restructure the audience's free time. In short, television became the time determiner of daily life.

According to the researchers who adopted Uses and Gratifications approach, the function of media is never limited to conveying information. No matter what type of medium it is (newspaper, television, radio etc), there is always something in it that would help the audience this or that way. These researchers say that, media has a therapeutic function for those who live forbidden experiences through celebrities; a relaxing function for those who use it for entertainment and a bonding function for those who use it to reinforce the practical and symbolic bonds within a society. Therefore, the studies based on uses and gratifications theory, try to identify the psychological situations as well as the needs that are thought to be fulfilled with the use of media (Bourse \& Yücel, 2012, p. 91). 
Table 1. Uses and Gratifications Studies on Television

\begin{tabular}{|c|c|c|}
\hline Researcher & Year & Factors/ Motivations / Gratifications \\
\hline Greenberg & 1974 & $\begin{array}{l}6 \text { factors: relaxation, companionship, learning, habit, arousal } \\
\text { and escape }\end{array}$ \\
\hline Blumler & 1979 & 4 factors: surveillance, diversion, curiosity, personal identity \\
\hline Rubin & $\begin{array}{l}1977 / \\
1979\end{array}$ & $\begin{array}{l}6 \text { factors: learning, to pass time, habit, companionship, } \\
\text { forget, arousal, relaxation }\end{array}$ \\
\hline Rubin & 1981 & $\begin{array}{l}9 \text { factors: pass time, companionship, arousal, content, } \\
\text { relaxation, information, escape, entertainment, social } \\
\text { interaction }\end{array}$ \\
\hline Rubin & 1981 & $\begin{array}{l}4 \text { factors: substitution, information seeking, entertainment, } \\
\text { time consumption }\end{array}$ \\
\hline Wenner & 1982 & $\begin{array}{l}4 \text { factors: surveillance, entertainment/diversion, interpersonal } \\
\text { utility and parasocial interaction }\end{array}$ \\
\hline Bantz & 1982 & $\begin{array}{l}4 \text { factors: companionship, surveillance, entertainment, } \\
\text { voyeurism }\end{array}$ \\
\hline Shaver & 1983 & $\begin{array}{l}14 \text { motivations: flexibility of programming, entertainment, } \\
\text { surveillance, ego gratification, religious programming, to } \\
\text { pass time, interpersonal utility, companionship, family } \\
\text { viewing, reception, parasocial interaction, uncensored films }\end{array}$ \\
\hline Abelman & 1988 & 6 factors: reaction, knowledge, faith, habit, escape \\
\hline Finn \& Gorr & 1988 & 2 factors: social compensation, mood management \\
\hline Babrow & 1989 & $\begin{array}{l}3 \text { factors: Anticipated social pleasure, learning, romantic } \\
\text { fantasy }\end{array}$ \\
\hline $\begin{array}{l}\text { Walker \& } \\
\text { Bellamy }\end{array}$ & 1991 & $\begin{array}{l}7 \text { factors: selective avoidance, annoying others, finding out } \\
\text { what's on TV, getting more from TV, avoiding commercials, } \\
\text { accessing music videos, accessing TV news }\end{array}$ \\
\hline $\begin{array}{l}\text { Conway \& } \\
\text { Rubin }\end{array}$ & 1991 & $\begin{array}{l}6 \text { factors: to pass time, entertainment, escape, information, } \\
\text { status enhancement }\end{array}$ \\
\hline Lin & 1993 & $\begin{array}{l}5 \text { factors: informational guidance, interpersonal } \\
\text { communication, parasocial interaction, entertainment, } \\
\text { diversion }\end{array}$ \\
\hline Lee \& Lee & 1996 & $\begin{array}{l}6 \text { factors: ritualized viewing, mood improvement, } \\
\text { informational/cognitive benefit, social learning, social } \\
\text { grease, a different world }\end{array}$ \\
\hline $\begin{array}{l}\text { Abelman/ } \\
\text { Atkin \& } \\
\text { Rand }\end{array}$ & 1997 & $\begin{array}{l}10 \text { factors: relaxation, companionship, habit, to pass time, } \\
\text { entertainment, social interaction, information, arousal, } \\
\text { escape, moral support }\end{array}$ \\
\hline
\end{tabular}

\section{Television Studies based on Uses and Gratifications Theory in Turkey}

The number of the television studies based on the Uses and Gratifications Theory in Turkey has increased parallel to the increase in the number of private television channels after the 1990s. Especially after the 2000's, several studies which interpret television viewing through this theory, were conducted in Turkey. 
Koçak (2001, p. 150), in his study on the behaviour of television audiences, their choices and gratifications, established that people watch television to gratify the needs of entertainment/relaxation/habit, moral support, information, companionship, economic information and escape.

There are similarities between the results obtained from Küçükkurt's study (2005) and that of previously conducted uses and gratifications studies in terms of television viewing habits and motivations. When these habits and motivations were compared with the participation of local communities and entertainment habits, significant interactions were identified. According to the research results, today, television is the most important means of entertainment. The number of people choosing the options decreases as the options change from "I don't participate to local entertainment communities" to "I often participate to local entertainment communities". Preferring to watch television is an important motivation for not participating in the entertainment communities and as the television viewing time increases, the participation level in the entertainment communities decreases. The more societies watch television, the less they participate in social activities, indicating that television plays an important part in the socialization of people.

According to the research conducted by Küçükkurt et al. (2009), television is the most frequently used mass media. Following the newspapers and magazines, it is the second most preferred medium in terms of obtaining information about Turkey and the world.

Çakır (2010) examined television dependency of television viewers using the Uses and Gratifications approach. The research, which was conducted in the city of Konya, revealed that all motivations, except for acquiring information make significant contributions to television dependency.

Akçay (2011) tried to identify television viewing motivations in his study and the five factors he came up with as a result of this study are spiritual support-relaxation and social sharing, to pass time, social escape and information.

Özarslan and Nisan (2011) examined television viewing habits and motivations in the city of Gümüşhane. In the research, which was conducted with 415 people, it was revealed that the most watched programs on television are news programs while the least watched ones are foreign TV series.

Based on the uses and gratifications approach, the aim of Çiçek's research (2012) was to explore the motivations of the academicians working at the Selçuk University for watching television advertisements. For this purpose, 386 academicians were surveyed in 17 faculties. The participants had the habit of watching television for 0-2 hours and their motivation was to obtain information. Within this context, majority of the participants indicated that they watch prime time newscasts regularly. The results of this research showed that television viewers have different viewing motivations depending on their socio-economic status. The motivation of students and young people for watching television is entertainment while that of academicians and educators is obtaining information. 
Another research, which showed that television viewing motivations vary depending on socio-economic status, was conducted by Avc1 and Sönmez (2013) in the city of Elazığ. In this research, they explored motivations for watching health programs on television and identified four factors that are obtaining information, habit, moral support/awareness and personal utility.

Koçer (2013) conducted his research on television viewing habits and motivations in the city of Kayseri and determined six factors that influence television viewing habits. The most important one of these factors was recreation and entertainment. "Obtaining information" was ranked as the second and "guidance" as the third important factor. Other factors were "companionship/escape", "socialisation" and "coming together and awareness".

In the study of Çakır and Bozkurt (2014), eight factors were identified to measure participant's motivations for watching television or gratifications from television viewing and these were (a) entertainment; (b) surveillance and interpersonal utility; (c) passing time and habit; (d) relaxation; (e) escape; (f) companionship; (g) social interaction; (h) information.

\section{Methodology of the Study}

The main purpose of this study is to identify television viewing habits and motivations of television audience living in Turkey in the sample taken in the city of Istanbul. The Uses and Gratifications Approach is applied to the study. A survey was conducted among university graduates who live in the city centre of Istanbul between the dates of May 15 - June 15, 2014. The sample is selected randomly from the university graduated population living in Istanbul.

The survey consists of three parts: in the first part demographics were examined, in the second par, television viewing habits and in the third part television viewing reasons and motivations are examined. The questionnaire form was pre-tested with 50 people. After the final controls, 833 university graduates were selected by a random sampling method and surveyed. The universe of the research is the university graduated population of Turkey. According to Turkish statistics constitution the university graduated people of Turkey consist of the $11 \%$ of the whole Turkish population. The number of university graduated people are 5 million 913 thousand 187 people. Whereas in Istanbul the university graduated population is the $15.01 \%$ of the city population (TÜIK, 2013). The limitation of this study is the age of 40 years old. University students between the age of 17 and 40 are taken to consideration.

The questions explored within the context of this study are:

- What are television viewing habits of university graduate television viewers in Turkey?

- What kind of television programs do university graduate television viewers prefer to watch?

- How do viewers watch televisions? 
- How often the viewers use television and other media?

- What are the motivations of viewers for watching television? What are the gratifications obtained?

- What is the relation between the motivations of TV audiences for television viewing and their demographics?

\section{Findings}

\section{Demographics}

$44.54 \%$ of the university graduates who participated the survey are below the age of $22,55.46 \%$ of them are 23 years old or older. $57.1 \%$ of the participants is male and $42.9 \%$ is female (Table 2).

Table 2. Demographics

\begin{tabular}{|l|l|c|c|}
\hline \multicolumn{2}{|c|}{ Age } & Frequency & Percentage \\
\cline { 2 - 4 } & 23 and below & 371 & 44.54 \\
\cline { 2 - 4 } & Total & 462 & 55.46 \\
\hline \multirow{3}{*}{ Gender } & Male & $\mathbf{8 3 3}$ & $\mathbf{1 0 0 . 0}$ \\
\cline { 2 - 4 } & Female & 418 & 50.18 \\
\cline { 2 - 4 } & Total & 415 & 49.82 \\
\hline
\end{tabular}

Source: Author's estimations.

\section{Frequency Analyses}

$41.2 \%$ of the participants indicated that they watch 1-3 hours of television per day while $33.6 \%$ of them watch less than 1 hour of television. $19.3 \%$ of the participants watch 4-5 hours of television and 5.9\% watch more than 5 hours per day. It is seen that most viewers tend to watch television between 20:00 and 23:00. 14.3\% of the participants watches television between 23:00-01:00 while 13.4\% watch between 18:00-20:00 (Table 3).

Table 3. TV Watching Hours and Time Slot

\begin{tabular}{|l|c|c|c|c|c|}
\hline $\begin{array}{l}\text { TV watching } \\
\text { hours (Daily) }\end{array}$ & Frequency & Percentage & $\begin{array}{c}\text { Time } \\
\text { slot }\end{array}$ & Frequency & Percentage \\
\hline 0-1 Hour & 280 & 33.6 & $\mathbf{0 7 - 1 0}$ & 14 & 1.7 \\
\hline 1-3 Hours & 343 & 41.2 & $\mathbf{1 4 - 1 8}$ & 21 & 2.5 \\
\hline 4-5 Hours & 161 & 19.3 & $\mathbf{1 8 - 2 0}$ & 112 & 13.4 \\
\hline 5 Hours and more & 49 & 5.9 & $\mathbf{2 0 - 2 3}$ & 567 & 68.1 \\
\hline Total & $\mathbf{8 3 3}$ & $\mathbf{1 0 0 . 0}$ & $\mathbf{2 3 - 0 1}$ & 119 & 14.3 \\
\hline \multicolumn{7}{|l|}{} & Total & $\mathbf{8 3 3}$ & $\mathbf{1 0 0 . 0}$ \\
\hline
\end{tabular}

Source: Author's estimations.

The participants were asked what type of television programs they enjoy watching. Since they were told that they could give multiple answers, the total 
number of answers are higher than the number of participants. According to Table 4, the type of program that the participants enjoy watching the most is television series. Foreign movies, football and prime time newscasts follow them.

Table 4. Favourite TV Program Type

\begin{tabular}{|l|l|c|c|}
\hline \multicolumn{2}{|l|}{$\begin{array}{l}\text { Favourite TV } \\
\text { Program Type }\end{array}$} & Frequency & Percentage \\
\cline { 2 - 4 } & Foreign movies & 371 & $16.30 \%$ \\
\cline { 2 - 4 } & Football & 343 & $15.00 \%$ \\
\cline { 2 - 4 } & Prime Time Newscasts & 287 & $12.60 \%$ \\
\cline { 2 - 4 } & Talk Shows & 287 & $12.60 \%$ \\
\cline { 2 - 4 } & Documentaries & 168 & $7.40 \%$ \\
\cline { 2 - 4 } & Music - Entertainment & 161 & $7.10 \%$ \\
\cline { 2 - 4 } & Discussion Programs & 133 & $5.80 \%$ \\
\cline { 2 - 4 } & Game shows/Quiz Shows & 133 & $5.80 \%$ \\
\cline { 2 - 4 } & Domestic movies & 119 & $5.20 \%$ \\
\cline { 2 - 4 } & Celebrity Magazine Shows & 70 & $4.00 \%$ \\
\cline { 2 - 4 } & Culture and Art Shows & 70 & $3.10 \%$ \\
\cline { 2 - 4 } & All & 28 & $3.10 \%$ \\
\cline { 2 - 4 } & Cooking Shows & 21 & $0.90 \%$ \\
\cline { 2 - 4 } & Daytime women's programs & 0 & $0.00 \%$ \\
\hline Total & & 2.282 & $100.00 \%$ \\
\hline
\end{tabular}

Source: Author's estimations.

The participants stated that they surf the channels (zapping) during the advertisements or when they are bored of the program they are currently watching (Table 5).

Table 5. Channel Surfing (Zapping) Habits

\begin{tabular}{|l|l|c|c|}
\hline \multicolumn{2}{|l|}{$\begin{array}{l}\text { How many times do } \\
\text { you ZAP in a day? }\end{array}$} & Frequency & Percentage \\
\cline { 2 - 4 } & At least 10 times & 350 & 42.0 \\
\cline { 2 - 4 } & $11-20$ times & 231 & 27.7 \\
\cline { 2 - 4 } & More than I can count & 91 & 10.9 \\
\cline { 2 - 4 } & Total & 161 & 19.3 \\
\hline \multirow{3}{*}{ When do you ZAP? } & When advertisements start & 436 & $\mathbf{1 0 0 . 0}$ \\
\cline { 2 - 4 } & When I am bored of the show & 357 & $42.9 \%$ \\
\cline { 2 - 4 } & $\begin{array}{l}\text { When I understand that it is a } \\
\text { rerun }\end{array}$ & 40 & $4.8 \%$ \\
\cline { 2 - 4 } & Total & $\mathbf{8 3 3}$ & $\mathbf{1 0 0 . 0 \%}$ \\
\hline
\end{tabular}

Source: Author's estimations.

University graduated population consider television as a means of entertainment. They indicated that they obtain information about television programs from social media sites or Internet sites. In addition to that, they stated that Internet and social media are more important than television (Table 6). 
Table 6. Frequency Analyses

\begin{tabular}{|c|c|c|c|}
\hline \multirow{5}{*}{$\begin{array}{l}\text { What does television } \\
\text { mean to you? }\end{array}$} & & Frequency & Percentage \\
\hline & $\begin{array}{l}\text { Means of } \\
\text { entertainment }\end{array}$ & 394 & $47.20 \%$ \\
\hline & $\begin{array}{l}\text { Means of news } \\
\text { source }\end{array}$ & 213 & $25.60 \%$ \\
\hline & $\begin{array}{l}\text { Means of obtaining } \\
\text { information }\end{array}$ & 133 & $16.00 \%$ \\
\hline & It means nothing & 93 & $11.20 \%$ \\
\hline \multicolumn{2}{|l|}{ Total } & 833 & $100.00 \%$ \\
\hline \multirow{6}{*}{$\begin{array}{l}\text { How do you get } \\
\text { information about a TV } \\
\text { program? }\end{array}$} & Social Media Sites & 305 & $36.60 \%$ \\
\hline & Internet Sites & 248 & $29.80 \%$ \\
\hline & Newspaper & 147 & $17.60 \%$ \\
\hline & Friends & 102 & $12.20 \%$ \\
\hline & Radio & 31 & $3.80 \%$ \\
\hline & Magazine & 0 & $0.00 \%$ \\
\hline \multicolumn{2}{|l|}{ Total } & 833 & $100.00 \%$ \\
\hline \multirow{5}{*}{$\begin{array}{l}\text { Which medium is more } \\
\text { important than TV? }\end{array}$} & Internet & 430 & $51.60 \%$ \\
\hline & Social Media & 302 & $36.30 \%$ \\
\hline & Newspaper & 61 & $7.30 \%$ \\
\hline & Radio & 27 & $3.20 \%$ \\
\hline & Magazine & 13 & $1.60 \%$ \\
\hline \multicolumn{2}{|l|}{ Total } & 833 & $100.00 \%$ \\
\hline
\end{tabular}

Source: Author's estimations.

The average number of television receivers in university graduated houses is two. Usually, four people live in the household. Most of the participants do not have pay television subscriptions. Digiturk is the paid platform with the highest number of subscribers (Table 7).

Table 7. Frequency Analyses

\begin{tabular}{|c|c|c|c|c|c|c|c|}
\hline & $f$ & $\%$ & & & $f$ & $\%$ \\
\hline \multirow{5}{*}{$\begin{array}{l}\text { Number } \\
\text { of TV } \\
\text { receivers } \\
\text { in your } \\
\text { house }\end{array}$} & 1 & 287 & 34.5 & \multirow{3}{*}{$\begin{array}{l}\text { Do you have } \\
\text { a pay TV } \\
\text { subscription? }\end{array}$} & Yes & 434 & 52.1 \\
\hline & 2 & 385 & 46.2 & & No & 399 & 47.9 \\
\hline & 3 & 140 & 16.8 & & Total & 833 & 100.0 \\
\hline & 4 & 21 & 2.5 & \multirow{5}{*}{$\begin{array}{l}\text { Which } \\
\text { platform do } \\
\text { you } \\
\text { subscribe to? }\end{array}$} & Digiturk & 294 & 35.3 \\
\hline & Total & 833 & 100.0 & & D-Smart & 91 & 10.9 \\
\hline \multirow{6}{*}{$\begin{array}{l}\text { Number } \\
\text { of people } \\
\text { in the } \\
\text { household }\end{array}$} & 1 & 84 & 10.1 & & $\begin{array}{l}\text { Kablo-TV - } \\
\text { Turk } \\
\text { Telekom }\end{array}$ & 77 & 9.2 \\
\hline & 2 & 154 & 18.5 & & $\begin{array}{l}\text { None / } \\
\text { Unanswered }\end{array}$ & 371 & 44.5 \\
\hline & 3 & 161 & 19.3 & & Total & 833 & 100.0 \\
\hline & 4 & 266 & 31.9 & & & & \\
\hline & More than 5 & 168 & 20.2 & & & & \\
\hline & Total & 833 & 100.0 & & & & \\
\hline
\end{tabular}

Source: Author's estimations. 
The participants stated that they watch television for 1-3 hours per day. They do not use radio every day. The ones, who said that they use radio daily, listen to radio less than 2 hours per day. In terms of frequency of Internet use, they use Internet for 3-5 hours per day. In terms of media use, it is seen that magazines are not used daily. However, magazine users spend at least one hour reading it. University graduates use social media daily. Social media, as the most used medium, is used for 3-5 hours per day (Table 8).

Table 8. Duration of Media Use

\begin{tabular}{|l|c|c|c|c|c|}
\hline Duration & TV & Radio & Internet & Magazine & Social Media \\
\hline At least 1 hour per day & 84 & 175 & 28 & 168 & 70 \\
\hline 1-2 Hours & 252 & 175 & 140 & 98 & 161 \\
\hline 2-3 Hours & 259 & 70 & 252 & 21 & 203 \\
\hline 3-5 Hours & 126 & 56 & 357 & 35 & 315 \\
\hline I do not use every day & 112 & 357 & 56 & 511 & 84 \\
\hline Total & $\mathbf{8 3 3}$ & $\mathbf{8 3 3}$ & $\mathbf{8 3 3}$ & $\mathbf{8 3 3}$ & $\mathbf{8 3 3}$ \\
\hline
\end{tabular}

Source: Author's estimations.

\section{Reliability Analysis}

Reliability value is the indicator of the level of yielding the same results in repeated measures. Therefore, survey questions are subjected to a reliability analysis. Cronbach's Alpha coefficient is used in reliability analysis. The related coefficient takes a value between 0 and 1 and as it gets closer to 1 , the reliability of the survey increases. When the coefficient is over 0.70 , it can be said that the survey is reliable. Cronbach Alfa value of the survey used in this study was determined as 0.935 . Therefore, it was observed that the survey yielded quite reliable results (Table 9).

Table 9. Reliability Coefficient

\begin{tabular}{|l|c|}
\hline Cronbach's Alpha & N \\
\hline 0.935 & 21 \\
\hline
\end{tabular}

\section{Factor Analysis}

Factor analysis is done by grouping the expressions to put in an order the opinions about a fact. This fact is considered and measured together with all different aspects that support each other. The factor analysis and factor loading of the expressions are presented in Table 10. 
Table 10. Factor Analysis

\begin{tabular}{|c|c|c|c|c|}
\hline & $\begin{array}{l}\text { Entertainment } \\
\text { - Relaxing }\end{array}$ & $\begin{array}{l}\text { Passing } \\
\text { Time }\end{array}$ & $\begin{array}{l}\text { Receiving } \\
\text { Information }\end{array}$ & $\begin{array}{c}\text { Social } \\
\text { Motives }\end{array}$ \\
\hline 1. I like watching TV & 0.720 & & & \\
\hline $\begin{array}{l}\text { 2. It makes me happy to watch } \\
\text { TV. }\end{array}$ & 0.746 & & & \\
\hline $\begin{array}{l}\text { 3. TV makes me feel less } \\
\text { lonely. }\end{array}$ & 0.657 & & & \\
\hline $\begin{array}{l}\text { 4. My mind gets distracted } \\
\text { while I watch TV. }\end{array}$ & 0.763 & & & \\
\hline 5. I laugh when I watch TV. & 0.669 & & & \\
\hline $\begin{array}{l}8 . \mathrm{TV} \text { relaxes me in the daily } \\
\text { hassle. }\end{array}$ & 0.684 & & & \\
\hline $\begin{array}{l}\text { 9. TV makes me forget my } \\
\text { problems at work and school. }\end{array}$ & 0.575 & & & \\
\hline $\begin{array}{l}\text { 13. I watch TV when I have } \\
\text { nothing to do. }\end{array}$ & & 0.565 & & \\
\hline $\begin{array}{l}\text { 14. TV is an alternative } \\
\text { medium to spend my free time. }\end{array}$ & & 0.605 & & \\
\hline 15. TV ends my loneliness. & & 0.546 & & \\
\hline $\begin{array}{l}\text { 17. TV helps me to get rid of } \\
\text { my boredom. }\end{array}$ & & 0.588 & & \\
\hline $\begin{array}{l}18 . \mathrm{TV} \text { is always on in my } \\
\text { house. }\end{array}$ & & 0.730 & & \\
\hline $\begin{array}{l}\text { 19. TV helps me to move away } \\
\text { from my family members and } \\
\text { friends sometimes. }\end{array}$ & & 0.708 & & \\
\hline $\begin{array}{l}\text { 20. It makes me forget the } \\
\text { problems in my daily life. }\end{array}$ & & 0.608 & & \\
\hline $\begin{array}{l}\text { 21. Watching TV is an excuse } \\
\text { for not going to places that I } \\
\text { don't like to be. }\end{array}$ & & 0.625 & & \\
\hline $\begin{array}{l}\text { 10. I learn the current events of } \\
\text { the world and country from TV }\end{array}$ & & & 0.798 & \\
\hline $\begin{array}{l}\text { 11. I learn the developments in } \\
\text { the country from prime time } \\
\text { newscasts on TV. }\end{array}$ & & & 0.863 & \\
\hline $\begin{array}{l}\text { 12. I am informed about current } \\
\text { topics in the agenda by watching } \\
\text { discussion programs on TV. }\end{array}$ & & & 0.779 & \\
\hline $\begin{array}{l}\text { 6. I like watching TV because } \\
\text { it brings us together as a } \\
\text { family. }\end{array}$ & & & & 0.761 \\
\hline $\begin{array}{l}\text { 7. I like watching TV with my } \\
\text { friends. }\end{array}$ & & & & 0.549 \\
\hline $\begin{array}{l}\text { 16. I like to watch and discuss } \\
\text { the speeches and comments } \\
\text { made by opinion leaders with } \\
\text { my friends. }\end{array}$ & & & & 0.627 \\
\hline
\end{tabular}

Source: Author's estimations. 
When motivations and gratifications, which are used in the measurement of television viewing habits of the university graduates, are observed, it is seen that "social motives" is the factor with the highest mean and "receiving information" is the one with the lowest mean (Table 11).

Table 11. Analysis of Factors

\begin{tabular}{|l|c|c|c|c|c|c|}
\hline & $\mathbf{N}$ & Minimum & Maximum & Mean & $\begin{array}{c}\text { Standard } \\
\text { Error }\end{array}$ & $\begin{array}{c}\text { Standard } \\
\text { Deviation }\end{array}$ \\
\hline $\begin{array}{l}\text { Relaxing - } \\
\text { Entertainment }\end{array}$ & 833 & 1.00 & 5.00 & 2.6651 & 0.08007 & 0.87342 \\
\hline Passing Time & 833 & 1.00 & 5.00 & 2.9233 & 0.07775 & 0.84812 \\
\hline $\begin{array}{l}\text { Receiving } \\
\text { Information }\end{array}$ & 833 & 1.00 & 5.00 & 2.5238 & 0.08838 & 0.96411 \\
\hline Social Motives & 833 & 1.00 & 5.00 & 3.0728 & 0.07898 & 0.86157 \\
\hline Scale & 833 & 1.00 & 5.00 & 2.8015 & 0.06703 & 0.73123 \\
\hline
\end{tabular}

Source: Author's estimations.

\section{Statistical Analyses}

T-tests and ANOVA analyses were conducted and motivations of university graduates were examined with respect to their demographics.

\section{T-Tests by Age}

T-tests results showed that, it is only the opinions about the "receiving information" function that vary depending on age at the significance level of 0.1 . Meaning that, interestingly, the university graduates who are 22 years old or younger see television as a means of receiving information more than the university graduates 23 years old or older. The new graduates attach more importance to the "receiving information" function. Older graduates attach less importance to the "receiving information" function of television. It may be said that, as people get older, they lose trust in television (Table 12). 
Table 12. T-Tests by Age

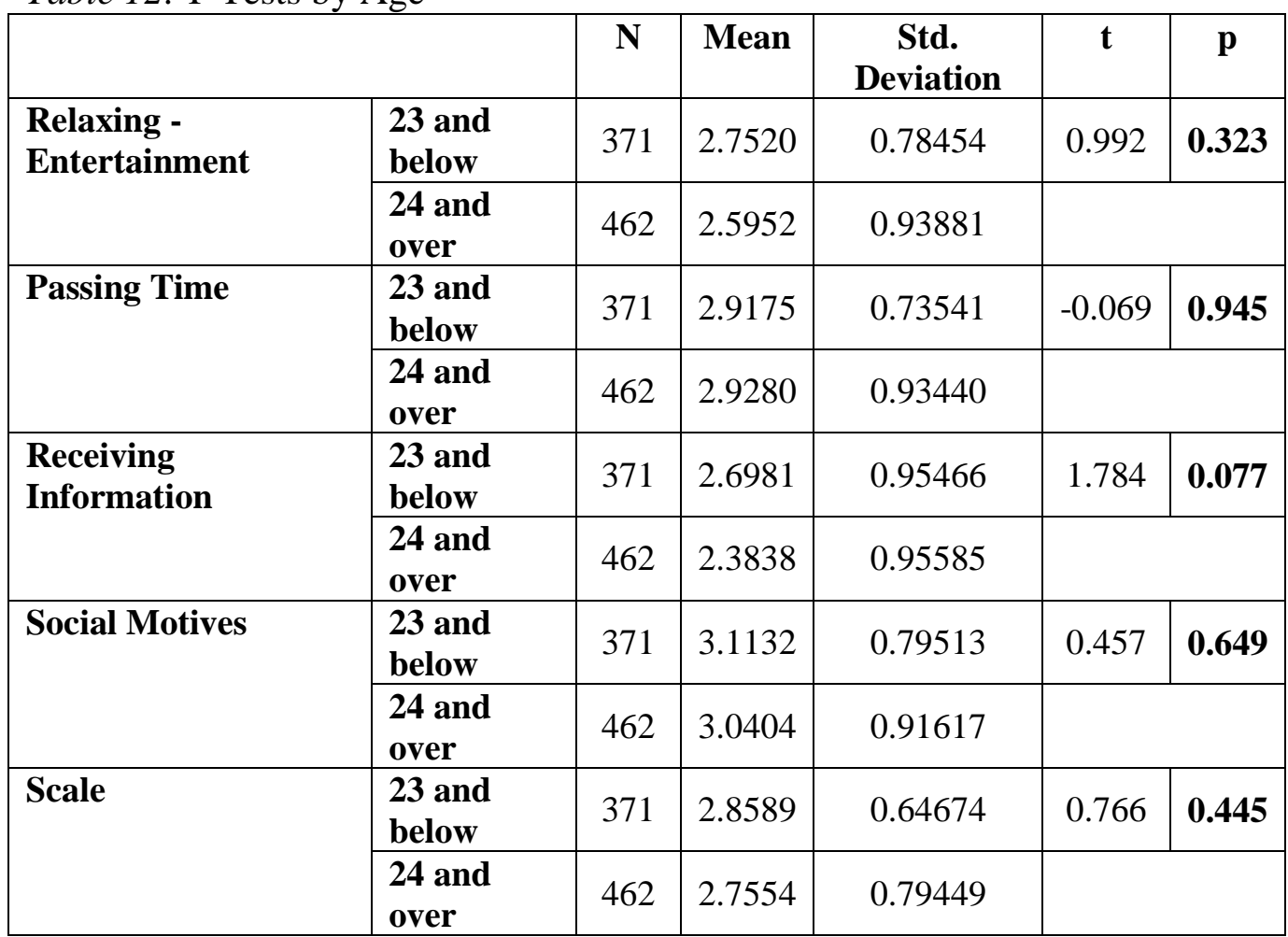

Source: Author's estimations.

\section{T-Tests by Gender}

$\mathrm{T}$ test results revealed that women watch television for "social motives" more than men do $(\mathrm{p}=0.029<0.05)$. It was also observed that women watch television with the purpose of "relaxing and entertainment" more than men $(\mathrm{p}=0.058<0.10)$. Opinions of women about the scale of 21 questions are more positive (at the significance level of 0.1$)$ than men $(0.076<0.10)$ (Table 13 ).

Table 13. T-Tests by Gender

\begin{tabular}{|l|l|c|c|c|c|c|}
\hline \multicolumn{2}{|c|}{} & $\mathbf{N}$ & Mean & Std. Deviation & $\mathbf{t}$ & $\mathbf{p}$ \\
\hline \multirow{2}{*}{$\begin{array}{l}\text { Relaxing - } \\
\text { Entertainment }\end{array}$} & Male & 418 & 2.5378 & 0.94281 & -1.916 & 0.058 \\
\cline { 2 - 8 } Passing Time & Female & 415 & 2.8347 & 0.74690 & \multicolumn{2}{|c|}{} \\
\hline \multirow{2}{*}{$\begin{array}{l}\text { Receiving } \\
\text { Information }\end{array}$} & Male & 418 & 2.8732 & 0.95600 & -0.779 & 0.437 \\
\cline { 2 - 8 } Social Motives & Female & 415 & 2.9902 & 0.68184 & \multicolumn{2}{|c|}{} \\
& Male & 418 & 2.4069 & 1.00223 & -1.537 & 0.127 \\
\cline { 2 - 8 } & Female & 415 & 2.6797 & 0.89681 & \multicolumn{2}{|c|}{} \\
\hline \multirow{2}{*}{ Scale } & Male & 418 & 2.9314 & 0.97320 & -2.218 & $\mathbf{0 . 0 2 9}$ \\
\cline { 2 - 8 } & Female & 415 & 3.2614 & 0.64744 & -1.790 & 0.076 \\
\hline
\end{tabular}

Source: Author's estimations. 


\section{ANOVA Comparison of TV Watching Hours Per Day}

ANOVA analysis results indicated that watching television for "relaxingentertainment" vary depending on television watching hours $(\mathrm{p}=0.010<0.05)$. Tukey Analysis was conducted to find out the source of the difference and it was determined that those who watch TV for 4-5 hours use it as a means of "relaxing-entertainment" more than those who watch TV less than 1 hour (Table 14).

Table 14. ANOVA Comparison of TV Viewing Hours Per Day

\begin{tabular}{|c|c|c|c|c|c|c|}
\hline & & $\mathbf{N}$ & Mean & $\begin{array}{c}\text { St. } \\
\text { Deviation }\end{array}$ & $\mathbf{F}$ & $\mathbf{p}$ \\
\hline \multirow{5}{*}{$\begin{array}{l}\text { Relaxing - } \\
\text { Entertainment }\end{array}$} & 0-1 Hour & 280 & $3.0143 *$ & 0.83663 & 3.973 & 0.010 \\
\hline & 1-3 Hours & 343 & 2.5685 & 0.82401 & & \\
\hline & 4-5 Hours & 161 & $2.4099 *$ & 0.94201 & & \\
\hline & $\begin{array}{l}5 \text { Hours and } \\
\text { more }\end{array}$ & 49 & 2.1837 & 0.59883 & & \\
\hline & Total & 833 & 2.6651 & 0.87342 & & \\
\hline \multirow[t]{5}{*}{ Passing Time } & 0-1 Hour & 280 & 3.1813 & 0.87932 & 2.004 & 0.117 \\
\hline & 1-3 Hours & 343 & 2.7908 & 0.84602 & & \\
\hline & 4-5 Hours & 161 & 2.7500 & 0.78877 & & \\
\hline & $\begin{array}{l}5 \text { Hours and } \\
\text { more }\end{array}$ & 49 & 2.9464 & 0.64087 & & \\
\hline & Total & 833 & 2.9233 & 0.84812 & & \\
\hline \multirow{5}{*}{$\begin{array}{l}\text { Receiving } \\
\text { Information }\end{array}$} & 0-1 Hour & 280 & 2.7500 & 0.85318 & 1.391 & 0.249 \\
\hline & 1-3 Hours & 343 & 2.4422 & 1.02602 & & \\
\hline & 4-5 Hours & 161 & 2.4348 & 1.01222 & & \\
\hline & $\begin{array}{l}5 \text { Hours and } \\
\text { more }\end{array}$ & 49 & 2.0952 & 0.85449 & & \\
\hline & Total & 833 & 2.5238 & 0.96411 & & \\
\hline \multirow[t]{5}{*}{ Social Motives } & 0-1 Hour & 280 & 3.2083 & 0.85631 & 1.324 & 0.270 \\
\hline & 1-3 Hours & 343 & 3.0680 & 0.80502 & & \\
\hline & 4-5 Hours & 161 & 3.0145 & 0.97171 & & \\
\hline & $\begin{array}{l}5 \text { Hours and } \\
\text { more }\end{array}$ & 49 & 2.5238 & 0.83571 & & \\
\hline & Total & 833 & 3.0728 & 0.86157 & & \\
\hline \multirow[t]{5}{*}{ Scale } & 0-1 Hour & 280 & 3.0679 & 0.70415 & 2.983 & \multirow[t]{5}{*}{0.034} \\
\hline & 1-3 Hours & 343 & 2.7065 & 0.71866 & & \\
\hline & 4-5 Hours & 161 & 2.6294 & 0.77717 & & \\
\hline & $\begin{array}{l}5 \text { Hours and } \\
\text { more }\end{array}$ & 49 & 2.5102 & 0.43271 & & \\
\hline & Total & 833 & 2.8015 & 0.73123 & & \\
\hline
\end{tabular}

Source: Author's estimations.

\section{ANOVA Comparison of TV Watching Time Slot}

ANOVA analysis showed that opinions about the "relaxing and entertainment" function and the overall scale vary depending on the time slot at 
the significance level of 0.1 (consecutively $\mathrm{p}=0.054$ and $\mathrm{p}=0.087<0.10$ ). It was observed that, after the Tukey analysis, this difference varied at the significance level of 0.1 again. According to this, people who watch television between 23:00-01:00, use television for "relaxation" more than the ones who watch TV between 20:00-23:00. The ones who watch TV between 20:0023:00, indicated that they watch television for "relaxation" more than the ones who watch TV between 18:00-20:00. As for the scale of 21 questions, as a result of Tukey analysis conducted, it was seen that, opinions of the ones who watch TV between 23:00-01:00 are more positive at the significance level of 0.1 than that of the ones who watch TV between 18:00-20:00 $(\mathrm{p}=0.087<0.10)$. According to this, dependency on motivations and factors identified for television is higher compared to those who watch TV at night (Table 15).

Table 15. ANOVA Comparison of TV Watching Time Slot

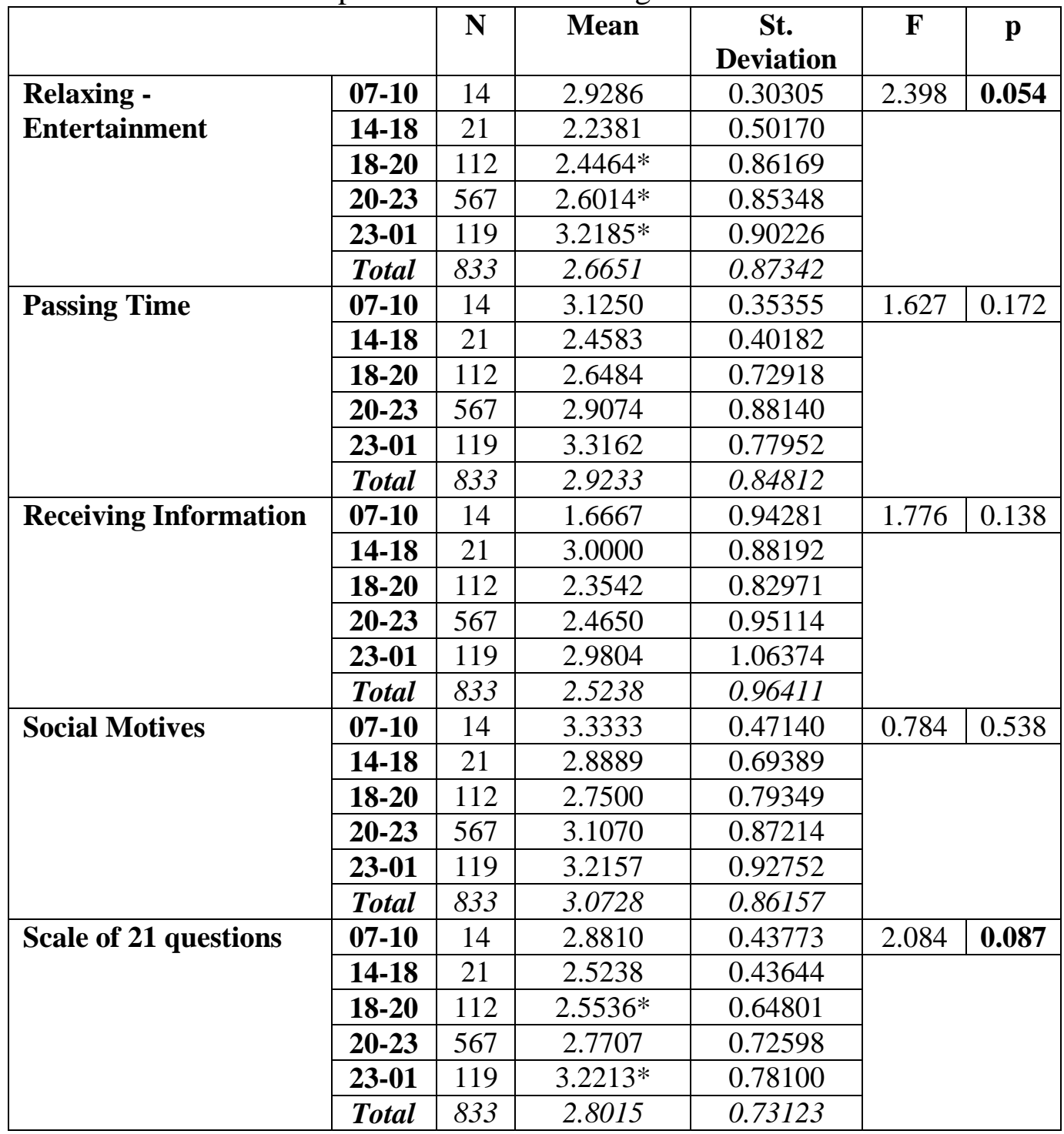

Source: Author's estimations. 


\section{Conclusions}

Uses and Gratifications theory is one of the basic approaches in interpreting mass communication. Uses and Gratifications researchers start out with two basic assumptions: first is that media audiences are variably active communicators. Researchers consider each individual who uses media as different personalities with different characteristics and needs; second is to explain the reasons of audience motivation and behaviours.

According to this approach, media users seek out specific media to satisfy felt needs or desires, which brings out the notion of "active audience" contrary to previous studies that saw audience members as "passive". It is also accepted that uses and gratifications approach rests upon two main assumptions: first that the psychological and social circumstances will have an effect on the media/communication choice of the individual; second that individuals seek to gratify the communication needs, which they cannot fulfil otherwise, by using mass media.

Uses and Gratifications approach is based on the notion that people's needs should be met and gratified. Mass media is considered to be one of the tools used for gratification. In order to gratify needs, people make selections among these tools and their products.

Within the context of the uses and gratifications approach, gratifications, which could be obtained by use of media, were classified. It could be seen that, uses and gratifications studies usually focus on motives such as "social integration (being in communication with others, feeling less lonely)", "personal identity (discovering oneself and others, understanding oneself)", "entertainment (relaxation, escape, passing time)" and "knowledge acquisition" with respect to use of media.

In this study, a survey was conducted on the television viewing habits of a sample of university graduates in the city of Istanbul. Through this survey, along with the way the university graduates use television, gratifications obtained by watching televisions (in terms of the Uses and Gratifications approach) were identified.

The survey was conducted to the university graduates who live in the city of Istanbul. According to the results of this survey, which was determined to yield reliable results; most of the university graduates watch 0-3 hours of television per day. Majority of university graduates watch television between 20:00-23:00, the time slot known as "prime time".

It was observed that the three most popular TV program types are consecutively "series", "foreign movies" and "football" and "news report" (the last two has the same percentage). The least watched TV programs are "daytime women's programs", "cooking shows" and "culture and art shows" and "celebrity magazine shows".

Usually, university graduates see television as a means of "entertainment". Most of the time, they receive the information about television programs from Internet and social media. This indicates the significance of social media and new media in the promotion of television. People acquire information about 
programs broadcasted on television -a traditional media- from social media and new media.

In parallel to this, majority of university graduates stated that Internet and social media are more important than television. Considered with the conclusion above, it could be said that Internet and Internet applications have a bigger place in the life of the participants compared to that of television and television has much of its lost value with the rise of the Internet.

There are one or two television receivers in university graduates' houses. More than half of the participants have pay TV subscriptions. Digiturk is the platform with the highest number of subscribers.

When duration of participants' media use was examined, it was determined that they watch television for 1-3 hours per day. They usually do not use radio every day. The one who use radio, listen to it for less than two hours per day. They use Internet for three to five hours per day.

University graduates use social media every day. They spend time using social media for three to five hours. These results support the fact that television has lost much of its value against Internet and social media.

The twenty-one expressions on the survey form were subjected to factor analysis. The expressions in the television viewing scale were grouped under "relaxing-entertainment", "passing time", "receiving information" and "social motives".

As a result of the analyses conducted, it was revealed that university graduates who are 22 years old or younger see television as a means of "receiving information" more than the ones who are 23 years old and older. It could be due to the fact that as people get older, they lose trust in television. Women watch television for 'social motives' more than men. The ones, who watch TV for four to five hours, view television more for "relaxingentertainment" than the ones who watch TV for less than an hour.

According to the results of the study, the first reason of university graduated population watching TV is "social motives". The second one is "passing time" whereas as "receiving information" is ranked as the last of these reasons. In the previous studies, "entertainment" motivation has always been prominent. The fact that, in this study, "socialization" became the highest motivation is a sign showing the possibility of getting different results from different sociocultural target audiences. University graduate viewers form a more conscious audience profile and do not pay much attention to the "entertainment" and "information giving" functions of television.

This study shows how social media as a tool of new media changed the function of TV in the world in the sample of Turkey and Istanbul. The most popular approach (Frame and Uses approach) which gives details about the needs of consumer showed that the new educated generation takes very different satisfactions from the TV and this effects the functions of TV. We can say the importance line of the media tools has changed. In the past TV was more popular than radio, today its still the same but internet and social media is more important than TV now. So every new generation changes the importance of media tools with the help of every new technology applied to media. 


\section{References}

Akçay, H. (2011). Kullanımlar ve Doyumlar Yaklaşımı Bağlamında Sosyal Medya Kullanımı: Gümüşhane Üniversitesi Üzerine Bir Araştırma (Social Media Usage in the sight of frame and gratification theory: A Research on Gümüşhane University). Gazi Üniversitesi Illetişim Fakültesi Journal 33.

Alikılıç, Ö., Gülay, G., Binbir, S. (2013). Kullanımlar ve Doyumlar Kuramı Çerçevesinde Facebook Uygulamalarının İncelenmesi (The Research of Facebook applications in the sight of frame and gratification theory). Iletişim Kuram ve Araştırma Journal 37.

Avc1, İ.B., Ve Sönmez, M.F. (2013). Sağlık İletişimi Bağlamında Bireylerin Televizyonda Yayınlanan Sağlık Programlarını İzleme Alışkanlıkları ve Motivasyonları: Elazı̆̆ Örneği (The habits and motivation of watching of the Health programs in the perspective of Health comunication) E-Gifder Journal 2(2): 119-138.

Aydın, O. Ş. (2007). Alımlama Araştırmaları ve Kültürel Çalışmalar Geleneğinin Katkıs1 (Reception Studies and the Contribution of Cultural Studies Tradition). Istanbul Ticaret Üniversitesi Sosyal Bilimler Journal 11.

Ayhan, B., Çavuş, S. (2014). İzleyici Araştırmalarında Değişim: Kullanımlar ve Doyumlardan Bağımlılığa (Change in Audience Studies From Uses and Gratifications to Addiction). Selçuk Üniversitesi İletişim Journal 8(2).

Aziz, A. (1982). Radyo ve Televizyonla Eğitim (Education with Radio and TV). Ankara: Sevinç Matbaası.

Bourse, M., Yücel, H. (2012). Iletişim Bilimlerinin Serüveni (The Story of Comunication Science). İstanbul: Ayrıntı Yayınları.

Çakır, V. (2010). Televizyon Bă̆ımlılı̆̆ (Television Addiction). Konya: Literatürk Yayınları.

Çakır, V., Bozkurt, Ö. (2014). Televizyon İzleme Alışkanlıkları Motivasyonları ve TRT 6: Hakkâri Örneği (Television Viewing Habits, Motivations and TRT 6: The Case of Hakkari) Global Media Journal 4(8).

Çaplı, B. (2008). Fili Tarif Etmek Özel Televizyona Beş Kala (Expressing the Elephant Five to Private TV). Ankara: İmge Yayınevi.

Çiçek, (2012). Akademisyenlerin Televizyon Reklamlarına Yönelik Motivasyonları Üzerine Bir Araştırma (A Research about the TV Ads Motivation of Academicians). Master Thesis. Konya: Selçuk University.

Dede, Y. (2011). Türkiye'de Görsel ve İsitsel Medya Pazarl Analizi (The Audio Visual Media Market in Turkey). Ankara: RTÜK

Demir, M. Ö., Demir, Z. G. (2013). The Uses and Gratifications Approach of TV Series Viewers in Turkey. Akademik Bakış Journal 39.

Fiske, J. (2003). İletişim Çalışmalarına Giriş (Translated By: S. İrvan). (Introduction to Communication Studies). Ankara: Bilim ve Sanat Yayınları.

Hüseyinoğlu, Ş. (2009). Evlerimizdeki Truva Atı: Televizyon [Trojan our home: TV]. İstanbul: Itidal Yayınları.

Karakoç, E., Gülsünler, E. M. (2012). Kullanımlar ve Doyumlar Yaklaşımı Bağlamında Facebook: Konya Üzerine Bir Araştırma (Facebook in the Sight of Uses and Gratifications Approach: A Research about Konya). Akdeniz Üniversitesi Illetişim Journal 18.

Koçak, A. (2001). Televizyon İzleyici Davranışları Televizyon İzleyicilerinin Tercihleri ve Doyumları Üzerine Teorik ve Uygulamalı Bir Çalışma (A 
Theoretical Study about the listeners TV watching Habits and their motivations). Phd Thesis. Konya: Selçuk University.

Koçer, M. (2013). Televizyon İzleme Alışkanlıkları ve Motivasyonları: Kayseri Örneği (Television Watching Habits and Motivations: The Sample of Kayseri). E-Journal of New World Sciences Academy 207-225.

Küçükkurt, M. (2005). Bir Sosyal Etkinlik Olarak Ĕglence ve Televizyon - Konya Örneği (TV as a social and entertainment environment - Example of Konya). PhD Thesis. Konya: Selçuk University.

Küçükkurt, M., Hazar, M., Çetin, M., Topbaş, H. (2009). Kullanımlar ve Doyumlar Yaklaşımı Perspektifinden Üniversite Öğrencilerinin Medyaya Bakışı (The Aspect of University Students to Media From Perspective of Uses and Gratifications Approach). Selçuk Üniversitesi İletişim Journal 6(1).

Lewis, J. (2008) Cultural Studies: Basics. London: Sage Publications.

Livaditi, J., Vassipoloulou, K., Lougos, C., Chorianopoulos, C. (2003). Needs and Gratifications for Interactive TV Applications: Implications for Designers. Proceedings of the 36th Hawaii International Conference on System Sciences (HICSS'03), January 6-9, 2003. Hawaii, USA: IEEE Computer Society.

Özarslan, H., Nisan, F. (2011) Kullanımlar ve Doyumlar Perspektifinden Televizyon İzleme Alışkanlıkları ve Motivasyonları: Gümüşhane Örneği (Television Watching Habits and Motivations From a Uses and Gratifications Perspective: The Example of Gumüşhane City). Gümüşhane Üniversitesi Iletişim Fakültesi Elektronik Dergisi 1(1), 24-43

Özçetin, B. (2010). Kullanımlar ve Doyumlar dan İzlerkitle Sosyolojisine: Türkiye’ de İzlerkitle Çalışmaları (The uses and gratification to rating sociology: The Audience Works in Turkey). İetişim Araştırmaları Dergisi 8(2), 9-46.

Ruggiero, T. E. (2000). Uses and Gratifications Theory in the 21st Century. Mass Communication \& Society 3(1).

Tezcan, M. (1982). Boş Zamanlar Sosyolojisi (The Sociology of Spare Time). Ankara: Ankara Üniversitesi Eğitim Bilimleri Fakültesi Yayınları, no. 174.

TÜiK (2014). Radyo ve Televizyon Kurum Istatistikleri [Radio and Television Institution Statistics]. Retrieved from http://www.tuik.gov.tr/PreTablo.do?alt_id= 1038. [Accessed: 2 July 2014]

TÜİK (2013). Türkiye Eğitim İstatistikleri (Turkish Education Statistics). Retrieved from http://www.tuik.gov.tr [Accessed from 1 August 2014]

Türkoğlu, N. (2007). İletişim Bilimlerinden Kültürel Çalışmalara Toplumsal İletişim (The Communication of Sociaty from Communication Science to Cultural Studies). İstanbul: Kalemus Yayınları.

Yaylagül, L. (2006). Kitle İletişim Kuramları (Mass Communication Theories). Ankara: Dipnot Yayınları.

Yumlu, K. (1994). Kitle Illetişim Kuram ve Araştırmaları (Mass Communication Theory and Researches). İzmir: Nam Yayınc1l1k. 